\section{Army Corps}

Engineers

vvaterways Experiment

Station

\title{
Stability of Calcium Chloroaluminate and Calcium Sulfoaluminate Phases in Hydraulic-Cement Mixtures
}

\author{
by Toy S. Poole \\ Structures Laboratory
}


by Toy S. Poole

Structures Laboratory

U.S. Army Corps of Engineers

Waterways Experiment Station

3909 Halls Ferry Road

Vicksburg, MS 39180-6199

Final report

Approved for public release; distribution is unlimited 


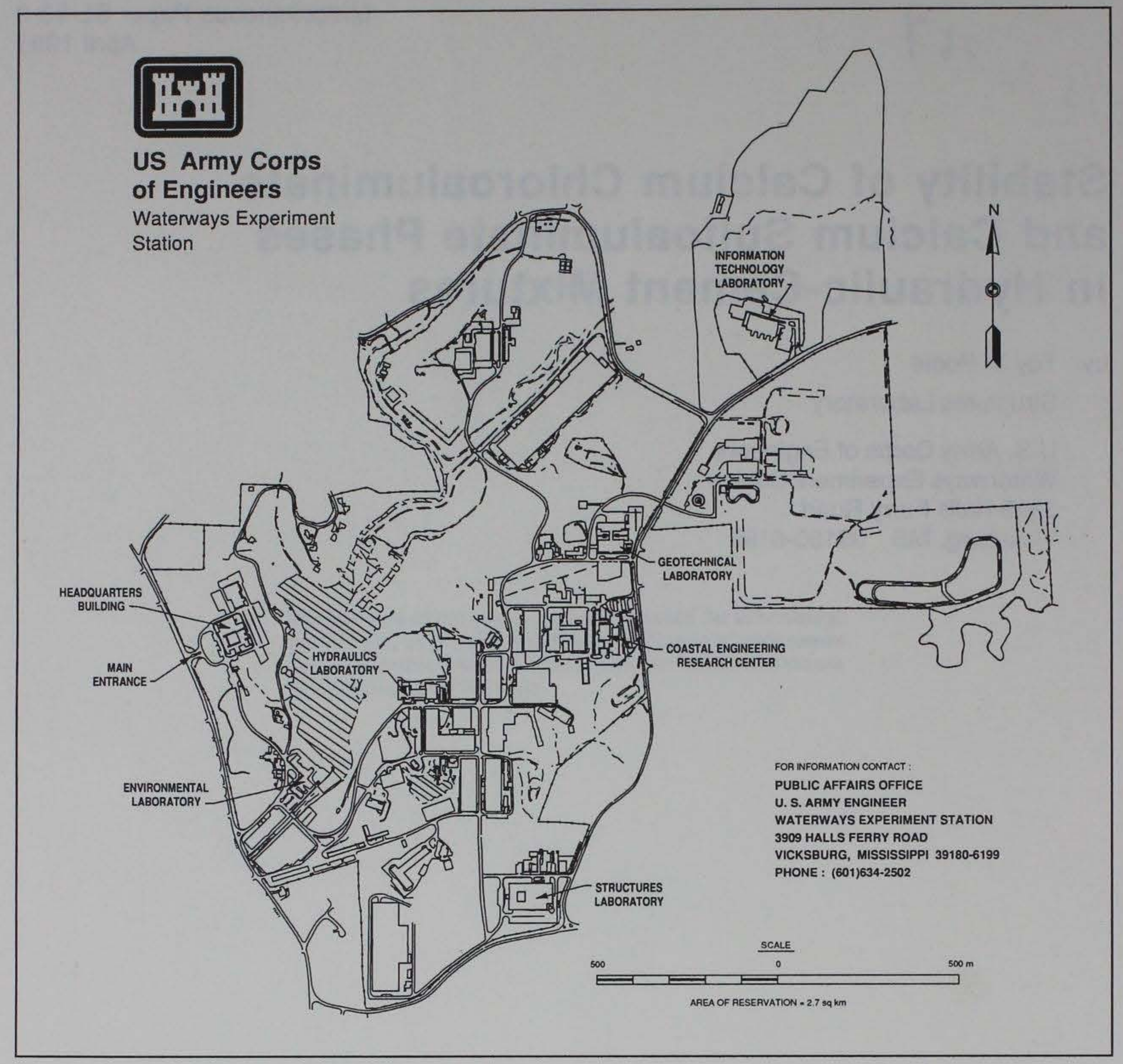

\section{Waterways Experiment Station Cataloging-in-Publication Data}

Poole, Toy S. (Toy Spotswood), 1946-

Stability of calcium chloroaluminate and calcium sulfoaluminate phases in hydraulic-cement mixtures / by Toy S. Poole ; prepared for U.S. Army Corps of Engineers.

20 p. : ill. ; $28 \mathrm{~cm}$. - (Miscellaneous paper ; SL-93-2)

Includes bibliographical references.

1. Concrete - Expansion and contraction. 2. Calcium aluminate.

3. Radioactive waste disposal in the ground. 4. Cement - Additives.

I. United States. Army. Corps of Engineers. II. U.S. Army Engineer Waterways Experiment Station. III. Title. IV. Series: Miscellaneous paper (U.S. Army Engineer Waterways Experiment Station) ; SL-93-2.

TA7 W34m no.SL-93-2 


\section{Contents}

Preface $\ldots \ldots \ldots \ldots \ldots \ldots \ldots \ldots \ldots \ldots \ldots \ldots$ iv

Conversion Factors, Non-SI to SI Units of Measurement . . . . . . . . v

1-Introduction $\ldots \ldots \ldots \ldots \ldots \ldots \ldots \ldots \ldots \ldots \ldots$

2-Data From Previous Work at WES $\ldots \ldots \ldots \ldots \ldots \ldots \ldots$

Three Types of Mixtures $\ldots \ldots \ldots \ldots \ldots \ldots \ldots \ldots \ldots$

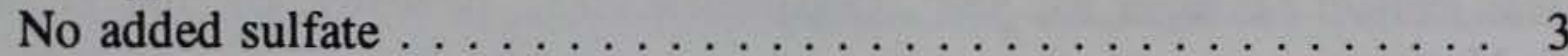

Low sulfate content $\ldots \ldots \ldots \ldots \ldots \ldots \ldots \ldots \ldots \ldots \ldots$

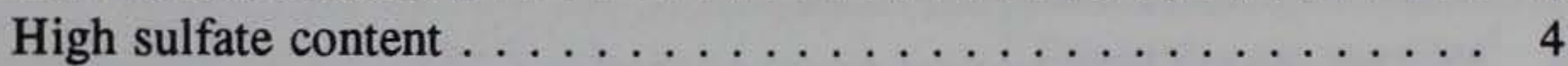

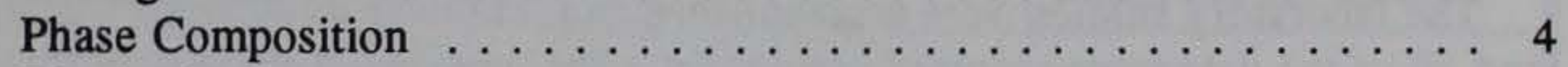

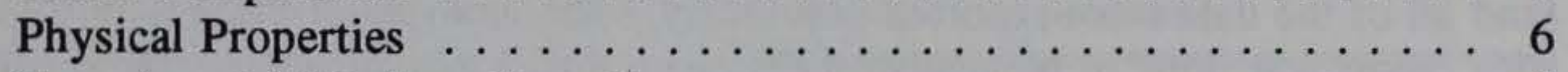

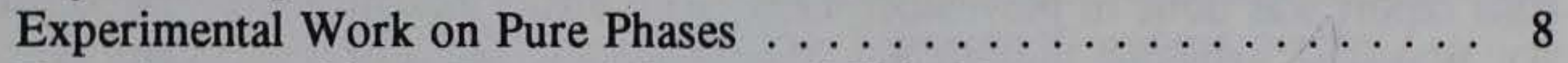

Experiments with an External Source of Chloride

or Sulfate $\ldots \ldots \ldots \ldots \ldots \ldots \ldots \ldots \ldots$

3-Discussion $\ldots \ldots \ldots \ldots \ldots \ldots \ldots \ldots \ldots \ldots \ldots \ldots \ldots$

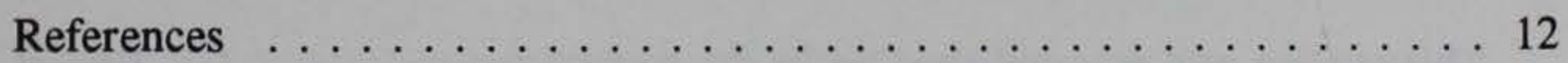

SF 298

\section{List of Tables}

Table 1. Data for Assorted Salt Bearing Paste, Grout, and

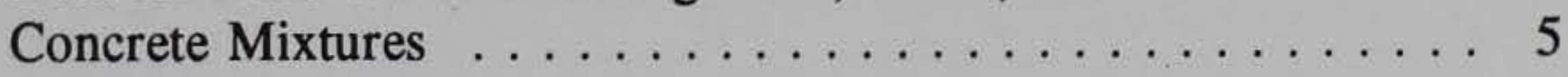

Table 2. Selected Physical-Properties Data for Borehole Plugging

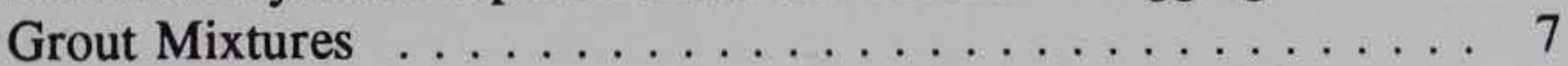

Table 3. Unconfined Compressive Strength (MPa) for ERDA-10

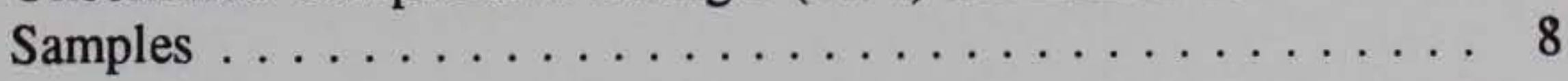

Table 4. Relative Amounts of Ettringite and Chloroaluminate in a Cement Paste as Determined by XRD . . . . . . . . . . . 10 


\section{Preface}

This work was performed for Sandia National Laboratories (SNL), supported by the U.S. Department of Energy, under contract DE-AC0476DP00789. The performing agency was the Concrete Technology Division (CTD), Structures Laboratory (SL), U.S. Army Engineer Waterways Experiment Station (WES), under SNL Document Number AA 2030.

Dr. Lillian D. Wakeley, WES, was Principal Investigator. Dr. E. J. Nowak was Project Manager for SNL, Department 6121, of which Dr. Joe Tillerson is Manager.

The laboratory studies were accomplished in CTD over a number of years and all of the data were reported previously. The analysis of these data for this report was done in November 1991, with direct guidance from Dr. Lillian D. Wakeley, principal investigator, Engineering Sciences Branch. The project plan was RPP 90-8 and RPP 90-8E. Dr. Toy S. Poole analyzed the data and wrote the report. This research was initiated by Mr. Alan D. Buck and by the late Ms. Katharine Mather, both formerly of WES.

This project was accomplished under the general supervision of Mr. Bryant Mather, Director, SL; Mr. James T. Ballard, Assistant Director, SL;

Mr. Kenneth L. Saucier, Chief, CTD.

At the time of publication of this report, Director of WES was Dr. Robert W. Whalin. Commander was COL Leonard G. Hassell, EN. 


\section{Conversion Factors, Non-SI to SI Units of Measurement}

Non-SI units of measurement used in this report can be converted to SI units as follows:

\begin{tabular}{||l|l|l|}
\hline Multiply & By & To Obtain \\
\hline \hline Fahrenheit degrees & $5 / 9$ & Celsius degrees or kelvins ${ }^{1}$ \\
\hline inches & 25.4 & millimetres \\
\hline \hline
\end{tabular}

1 To Obtain Celsius (C) temperature readings from Fahrenheit (F) readings, use the

following formula: $C=(5 / 9)(F-32)$. To obtain kelvin $(K)$ readings, use $K=(5 / 9)(F-32)$

+273.15 . 


\section{Introduction}

Throughout the 1980's, expansive behavior was one of the principal design criteria for grouts and concretes to be used in underground nuclear-waste repository sealing. The purpose of this requirement was to make a material that would fit tightly into the host-rock cavity that it is designed to seal. In work to date, expansion has been generated by inducing the formation of tetracalcium aluminate trisulfate-32-hydrate (ettringite) from the reaction between the calcium aluminates or anhydrous calcium sulfoaluminates in the cementitious materials and the calcium sulfates added to the system. This is known to cause expansive behavior under certain conditions (Poole and Wakeley 1992). Another design criterion has been that mixtures cannot cause dissolution of the host rock. This is not normally a problem with most host rocks, but can be a substantial problem when placing concrete in rocks composed of water-soluble minerals. In the case of rocks composed of halite $(\mathrm{NaCl})$, this problem has been solved by saturating the mixing water with sodium chloride. As a result, tetracalcium aluminate dichloride-10-hydrate (chloroaluminate) forms from the calcium aluminates in the cementitious materials. This phase is mildly expansive. So, in hydrated systems, at least two forms of hydrated calcium aluminates may coexist, or one may form preferentially, or one may replace the other, depending on the chemical environment.

Much of the research performed during the 1980's at the Waterways Experiment Station (WES) on geochemical stability of sealing materials for the WIPP focused on these questions: (a) do these interconversions occur under the conditions likely to be encountered in situ, and (b) do such interconversions affect the performance of the material. This report summarizes past work that addresses this point, and presents the results of a laboratory study performed at the Waterways Experiment Station (WES) and is intended to give some insight into these questions. The laboratory work was intended to determine the conditions under which such interconversions occur and did not focus on long-term performance properties.

The scenario in which this was first considered a potential problem involves the long-term behavior of a salt-saturated, expansive concrete or grout. It is expected that both chloroaluminate and ettringite will form during initial hydration but in the high-chloride environment, chloroaluminate may replace ettringite, potentially causing some changes in microstructure that would affect properties and performance of the concrete. Another potential scenario would 
be the case where sulfate ion becomes available from an external source. This could cause the conversion of chloroaluminate to ettringite, with unknown consequences.

The theoretical equilibrium between ettringite and chloroaluminate could be calculated for various conditions if the heat of formation of the individual compounds were known. These values are well known for the simple compounds involved, and estimates of values for ettringite have been published (Grutzeck and Roy 1985). No estimate of the heat of formation of chloroaluminate were found. Therefore, evaluation of this problem depends entirely upon empirical evidence. The literature on this subject is not extensive.

Lerch, Ashton, and Bogue (1929) evaluated the relationship between these two compounds in pure-phase aqueous systems. They found ettringite to be the most stable phase as long as there were sulfate ions in solution.

Roberts (1962) investigated the stability of pure chloroaluminate exposed to solutions containing both calcium sulfate and calcium sulfate plus calcium hydroxide. Calcium sulfate concentrations were adjusted to approximate the sulfate-alumina ratio in portland cement. His measure of stability was the appearance of calcium chloride in solution. The presence of calcium sulfate ion in solution resulted in a considerable increase in calcium chloride put into solution. He concluded that the calcium sulfate was substituting for the calcium chloride, i.e. ettringite was forming at the expense of chloroaluminate. $\mathrm{He}$ did not verify this analytically.

Ben-Yair (1974) also investigated the relationship between ettringite and chloroaluminate in pure-phase aqueous systems (this reference actually summarizes his earlier work on pure-phase systems). He found that ettringite crystal growth rates were enhanced by the presence of chloroaluminate. In the new work reported in the 1974 reference, he found that expansion of paste bars stored in mixed chloride-sulfate solutions was greater than that of bars stored in pure sulfate solutions. These results do not directly address the question of relative stability of ettringite and chloroaluminate, but the relationship between the two phases is probably involved in the observed phenomena.

Ogawa and Roy (1981) investigated the stability of ettringite in 20 percent sodium chloride solution. Ettringite was stable up to $95^{\circ} \mathrm{C}$, but was decomposed to gypsum and chloroaluminate between $95^{\circ} \mathrm{C}$ and $105^{\circ} \mathrm{C}$. Ettringite normally decomposes at about $40{ }^{\circ} \mathrm{C}$ higher than this range.

Jensen and Pratt (1989) reported that both chloroaluminate and ettringite formed rapidly when pastes were mixed with sea water, but that the chloroaluminate was readily replaced by ettringite in pastes stored in sea water, due to the higher availability of sulfate ion. This may take some time since the sulfate ion has to penetrate through the paste. Their work focused on 0.45 w/c pastes stored in sea water. In this context, chloroaluminate began to be replaced in measurable quantities after about 90 days. 


\section{Data From Previous Work at WES}

Ten mixtures containing both chlorides and sulfates have been examined at WES for phase composition, including an assessment of the relative abundance of ettringite and chloroaluminate. These mixtures were made from a variety of initial concentrations of sulfates and chlorides and so may be of some use in evaluating the equilibrium between chloroaluminate and ettringite. Ten of the mixtures were made with mixing water that was saturated with respect to sodium chloride. The remaining mixture was made with water that was about half-saturated with sodium chloride. Sulfate (expressed as $\mathrm{SO}_{3}$ ) levels varied widely, ranging from less than 1 percent to 8 percent.

\section{Three Types of Mixtures}

Mixtures are grouped according to sulfate contents, as follows.

\section{No sulfate added to the mixture}

This group is comprised of three mixtures that were not expansive. Two mixtures were made with portland cement and water saturated with sodium chloride. A third mixture was made with 75 percent of the cement replaced by ground granulated blast-furnace slag. Phase compositions were monitored by X-ray diffraction (XRD) for 1 year. These mixtures were part of work relating to alkali-silica reaction.

\section{Low sulfate content}

This group is comprised of three relatively complex mixtures that were either not expansive or were mildly expansive. Water-cement ratios $(\mathrm{w} / \mathrm{c})$ were relatively high $(>0.4)$. Phase composition was monitored for 3 to 4 years. Data on two of the mixtures were reported by Boa (1978) and by Gulick (1978). Later-age data were reported by Gulick, Boa, Walley, and Buck (1980); Rhoderick and Buck (1981); and Gulick, Boa, and Buck (1982). The third mixture (ERDA-10) was reported by Gulick (June 1979); Gulick, Boa, Walley, and Buck (1980); Gulick, Boa, and Buck (May 1980); Buck, 
Burkes, and Rhoderick (1981), and Gulick, Boa, and Buck (1982). Actually there were three ERDA-10 mixtures, but they may be effectively considered as one mixture for the present purpose. This is the only well-documented case where field-cast mixtures were placed in a deep borehole and then removed by coring for examination and testing in the laboratory.

\section{High sulfate content}

This group includes both grout and concrete mixtures. They are complex mixtures that are characterized by being the first to incorporate low ratios of water to cementitious solids (about 0.3 for the grout), and by being expansive due to the use of calcium sulfate hemihydrate (plaster of paris). Three of these are known as part of the Bell Canyon Test 1-F series (BCT 1-F). A fourth mixture, called expansive salt-saturated concrete (ESC), contained the most sulfate. Different mixtures have now been monitored by XRD for phase composition for periods of 1 to 3 years. There is limited information available for this series, especially the grout, since emphasis shifted in 1980 from plans to do sealing in a rock-salt host rock using salt-based mixtures to placement of nonsalt-based mixtures against an anhydrite host rock. Pertinent reports include Gulick, Boa, and Buck (Dec 1980); Buck (1985a); and Roy, Grutzeck, Mather, and Buck (1982). ESC was reported by Wakeley and Walley (1986), except that some data on phase composition are unreported.

\section{Phase Composition}

Pertinent data for the twelve mixtures are summarized in Table 1. Several general patterns can be deduced from these data, as follows.

a. The presence of ettringite does not increase with increasing sulfate content of the mixtures, except in ESC, which had the highest sulfate content.

$b$. There is no clear relationship between the presence and amount of chloroaluminate and amount of chloride or the ratio of chloride to sulfate.

c. Chloroaluminate is the dominant phase in most, but not all, mixtures.

d. Coexistence of both phases for several years $(\leq 4)$ is more common than replacement of ettringite by chloroaluminate, but replacement did occur in the ERDA-10 and ESC mixtures. There was no evidence that any chloroaluminate was replaced by ettringite.

e. The range of storage temperatures $\left(73\right.$ to $\left.130^{\circ} \mathrm{F}\right)$ did not seem to have any effect. 
Table 1

Data for Assorted Salt Bearing Paste, Grout, and Concrete Mixtures

\begin{tabular}{|c|c|c|c|c|c|c|c|}
\hline Mixture & $\begin{array}{l}\text { Amount of } \\
\mathrm{SO}_{3}, \%^{1}\end{array}$ & $\begin{array}{l}\text { Amount of } \\
\mathrm{Cl}, \%^{1}\end{array}$ & $\begin{array}{l}\text { Ratio } \\
\mathrm{Cl} / \mathrm{SO}_{3}\end{array}$ & $\begin{array}{l}\text { Mixture } \\
\text { Characterization }\end{array}$ & $\begin{array}{l}\text { Mixture } \\
\text { Environment }\end{array}$ & Phase Composition, XRD & $\begin{array}{l}\text { Physical } \\
\text { Data }\end{array}$ \\
\hline \multicolumn{8}{|c|}{ No Added Sulfate } \\
\hline $\begin{array}{l}\text { 1. RC } 756(3), 75 \% \\
\text { slag }\end{array}$ & 0.6 & 8.0 & 15 & \multirow[t]{3}{*}{$\begin{array}{l}\text { No added } \mathrm{SO}_{3} \text {, } \\
\text { Non expansive }\end{array}$} & \multirow[t]{3}{*}{$\begin{array}{l}\text { Sealed vials at } \\
100^{\circ} \mathrm{F}\end{array}$} & \multirow{3}{*}{$\begin{array}{l}\text { Chloroaluminate; early trace of } \\
\text { ettringite that disappeared within } \\
\text { a few days }\end{array}$} & \\
\hline 2. RC 705 & 1.1 & 6.5 & 6 & & & & \\
\hline 3. RC $688(3)$ & 1.7 & 6.5 & 4 & & & & \\
\hline \multicolumn{8}{|c|}{ Low Sulfate Content } \\
\hline 4. ERDA-10 & 1.2 & 7 & 6 & Non expansive & $\begin{array}{l}\text { Wet, } 73^{\circ} \mathrm{F} \text { to } \\
130^{\circ} \mathrm{F}\end{array}$ & $\begin{array}{l}\text { Minor ettringite replaced by } \\
\text { chloroaluminate, monitored } 3 \\
\text { years }\end{array}$ & Table 3 \\
\hline 5. Borehole plugging & 1.7 & 6 & 3.5 & \multirow{2}{*}{$\begin{array}{l}\text { High water } \\
\text { content }\end{array}$} & \multirow{2}{*}{$\begin{array}{l}\text { Wet and dry, } \\
73^{\circ} \mathrm{F} \text { to } 120^{\circ} \mathrm{F}\end{array}$} & \multirow{2}{*}{$\begin{array}{l}\text { Chloroaluminate and minor } \\
\text { ettringite, monitored } 4 \text { years }\end{array}$} & \multirow[t]{2}{*}{ Table 2} \\
\hline 6. Borehole plugging & 2.9 & 6 & 2 & & & & \\
\hline \multicolumn{8}{|c|}{ High Sulfate Content } \\
\hline 7. BCT 1-F Grout & 5 & $4 \cdot$ & 0.8 & \multirow[t]{2}{*}{$\begin{array}{l}\text { Expansive, low } \\
\text { water content }\end{array}$} & $\begin{array}{l}\text { Wet and dry, } 78 \text { - } \\
128^{\circ} \mathrm{F}\end{array}$ & \multirow[t]{2}{*}{$\begin{array}{l}\text { Chloroaluminate and minor } \\
\text { ettringite, monitored } 2 \text { years }\end{array}$} & see text \\
\hline $\begin{array}{l}\text { 8. Plug Test Matrix } \\
\text { Grout }\end{array}$ & 5 & 4 & 0.8 & & Dry $73^{\circ} \mathrm{F}$ & & \\
\hline 9. PSU-WES Grout & 5 & 2 & 0.4 & & $\begin{array}{l}\text { Sealed vials in } \\
\text { lime solution, } \\
100^{\circ} \mathrm{F}\end{array}$ & $\begin{array}{l}\text { Ettringite and minor chloro- } \\
\text { aluminate, monitored to } 1 \text { year }\end{array}$ & \\
\hline 10. ESC Concrete & 8 & 5 & 0.6 & $\begin{array}{l}\text { Higher } \mathrm{SO}_{3}, \text { more } \\
\text { expansive }\end{array}$ & $\begin{array}{l}\text { Sealed vials, } \\
100^{\circ} \mathrm{F}\end{array}$ & $\begin{array}{l}\text { More ettringite than chloro- } \\
\text { aluminate for } .5 \mathrm{yr} \text { and then } \\
\text { reverse through } 1 \text { year }\end{array}$ & \\
\hline
\end{tabular}


The moisture condition of storage is the parameter that has to be considered before drawing firm conclusions. This is because some storage was dry, and chemical reactions effectively stop when the internal relative humidity falls below 80 percent. Storage in sealed vials will, in cases where the original $\mathrm{w} / \mathrm{c}$ is lower than $\mathbf{0 . 4}$, amount to dry storage. Other storage conditions ranged from inundation to air at 100 percent relative humidity. Lack of free moisture may have retarded reactions in some cases.

\section{Physical Properties}

Physical properties data are available for the low-sulfate mixtures (mixtures 4,5 , and 6 , Table 1 ). These mixtures were characterized as containing minor ettringite that was replaced, in some mixtures, by chloroaluminate. Selected dynamic modulus of elasticity and compressional wave velocity data for two borehole plugging grout mixtures are shown in Table 2 for ages to 4 years. There were no significant decreases in either property. Compressive strength at 28 days only is also shown. All of these data are from Gulick, Boa, and Buck (1982).

Similar data, including compressive strength, to slightly over 3 years are shown in Table 3 for ERDA-10 grout mixtures stored in saturated sodium chloride solutions. These data are also from Gulick, Boa, and Buck (1982). There were no significant decreases in strength through this period.

A variety of data is available for the high-sulfate mixtures. No long-term data have been published for the original BCT 1-F mixtures or the later plug test matrix grout (mixtures 7 and 8, respectively, Table 1). However, the report on a sanded version of the BCT 1-F grout (Buck, Boa, and Walley 1985 ) included data to 1 year. Expansion data were monitored through 3-1/2 years for this material. Restrained expansion of moist-cured specimens at $23{ }^{\circ} \mathrm{C}$ is greater than 0.5 percent; expansion of more than 0.3 percent was observed from a similar mixture cast later. Thus, there is no recognizable degradation of these specimens, at least as determined from length-change data. The report on BCT 1-F salt concrete by Buck (1985b) included data through 1 year. Unrestrained expansion at that point was 0.18 percent. These bars had been monitored, but data not reported, through 4 years. Expansions for specimens moist cured at $23{ }^{\circ} \mathrm{C}$ was continuous and exceeded 0.25 percent at that time. Both restrained and unrestrained expansion of specimens cast in 1984 and kept in the same type of environment had been continuous and ranged from $>0.2$ percent to $>0.6$ percent during 3 years of monitoring. None of these expansion results suggest any detrimental effects due to high salt concentrations in the mixtures. Various data for the lowersalt PSU-WES grout (mixture 9, Table 1) were reported through 1 year (Roy, Grutzeck, Mather, and Buck 1982). Although there was some cracking due to expansion, the data did not show significant degradation in physical properties that would be attributable to the use of salt. 


\begin{tabular}{|c|c|c|c|c|}
\hline \multirow[b]{2}{*}{ Property } & \multicolumn{4}{|c|}{ Age } \\
\hline & 28 days & 1 year & 2 years & 4 years \\
\hline \multicolumn{5}{|c|}{ Borehole Plugging Grout made with Chem Comp Cement (Mixture 6, Table 1) } \\
\hline Compressive Strength, MPa (psi) & $37(5380)$ & n.d. ${ }^{2}$ & n.d. & n.d. \\
\hline $\begin{array}{l}\text { Dynamic Modulus of Elasticity, MPa } \times 10^{3} \text { (psi } \\
\left.\times 10^{6}\right)\end{array}$ & $13.4(1.94)$ & $15.0(2.17)$ & $15.7(2.27)$ & $15.6(2.26)$ \\
\hline Compressional Wave Velocity, $\mathrm{m} / \mathrm{s}$ (fps) & $3,179(10,430)$ & $3,299(10,820)$ & $3,499(11,315)$ & $3,516(11,532)$ \\
\hline \multicolumn{5}{|c|}{ Borehole Plugging Grout made with Type III Portland Cement (Mixture 5, Table 1) } \\
\hline Compressive Strength, $\mathrm{MPa}$ (psi) & $35(5060)$ & n.d. & n.d. & n.d. \\
\hline $\begin{array}{l}\text { Dynamic Modulus of Elasticity, } \mathrm{MPa} \times 10^{3}(\mathrm{psi} \\
\left.\times 10^{6}\right)\end{array}$ & $14.5(2.10)$ & $16.3(2.36)$ & $16.1(2.33)$ & $15.2(2.20)$ \\
\hline Compressional Wave Velocity, $\mathrm{m} / \mathrm{s}$ (fps) & $3,310(10,860)$ & $3,403(11,165)$ & $3,479(11,415)$ & $3,165(10,381)$ \\
\hline
\end{tabular}




\begin{tabular}{|l|l|l|l||}
\hline \hline \multicolumn{4}{||l||}{$\begin{array}{l}\text { Table } 3 \\
\text { Unconfined Compressive Strength (MPa) for ERDA-10 Samples }\end{array}$} \\
\hline \hline Specimen Type & 28 days & 27 months & 38 months \\
\hline \hline Plug 1, cast & 12.4 & 27.0 & 30.3 \\
\hline Plug 1, cored & 12.0 & 22.5 & \\
\hline Plug 2, cast & 15.4 & 26.7 & 28.1 \\
\hline ' From Gulick, Boa, and Buck (1982). & & \\
\hline
\end{tabular}

Physical data for the more expansive salt saturated ESC concrete (mixture 10, Table 1; Wakeley and Walley 1986) includes expansion data through 270 days that do not show any degradation (i.e. loss of expansion).

\section{Experimental Work on Pure Phases}

Additional research at the WES in 1986 focused on phase changes in a series of mixtures based on pure phases. Samples were prepared from the following mixtures:

86-04. $\mathrm{C}_{3} \mathrm{~A}$, plaster, and deionized water.

86-05. $\mathrm{C}_{3} \mathrm{~A}$, plaster, and saturated salt water.

86-06. $\mathrm{C}_{3} \mathrm{~A}$, more plaster, and saturated salt water.

86-07. $\mathrm{C}_{3} \mathrm{~A}$, and saturated salt water.

86-08. Mixture 86-04 was later repeated using the stoichiometric amounts of $\mathrm{C}_{3} \mathrm{~A}$ and plaster to make ettringite.

The intent of the pure-phase mixtures was to make ettringite (86-04) or chloroaluminate $(86-07)$ or both $(86-05,06)$ and monitor these mixtures by XRD for 1 year to document phase changes. When it was found that some of the original material always remained in each mixture, the bulk of the work was terminated. The rationale was that it would not be possible to distinguish between phases that were made as a result of reactions with the as yet unreacted $\mathrm{C}_{3} \mathrm{~A}$, or conversions between ettringite and chloroaluminate. Final examination was made at the 1 -year age.

This work was judged to be generally nonproductive because of this nonideal chemistry and because specific knowledge of moisture conditions during storage is sketchy. Lack of adequate moisture could be responsible for some of the results. The two mixtures with both salt and plaster $(86-05,06)$ formed ettringite but no chloroaluminate through 1 year. This is a complete reversal of everything that is shown in Table 1 . The failure to make chloroaluminate 
as expected could be due to an unusually high sulfate content (10 - 13 percent) or lack of adequate moisture during storage for the reaction to occur. Another possibility is a catalyst effect of cement that is missing in the pure $\mathrm{C}_{3} \mathrm{~A}$ paste. The fact that the mixture, made with $\mathrm{C}_{3} \mathrm{~A}$ and salt but no plaster (86-07), did make chloroaluminate makes the last possibility seem unlikely. No further attention will be paid to the pure-phase mixtures in this report.

\section{Experiments with an External Source of Chloride or Sulfate}

Some of the XRD monitoring of phase composition of mixtures shown in Table 1 indicated a preferential formation of chloroaluminate over ettringite, while other results indicated long-term coexistence of both phases (Table 1). Therefore, an experiment was conducted to determine if previously formed ettringite would be replaced by chloroaluminate during later exposure to a saturated salt solution. Low-alkali, high $\mathrm{C}_{3} \mathrm{~A}$ cement (RC-688(3)) was combined with water to make a paste with $0.5 \mathrm{w} / \mathrm{c}$ ratio. This paste was placed in sealed vials for about 1 month at a temperature of about $23{ }^{\circ} \mathrm{C}$. A sawed and ground surface (about 1 by 1.5 in) of paste was then examined by XRD to obtain a semiquantitative measure of ettringite content. This sample was then placed in a solution saturated with calcium sulfate for another month to encourage formation of more ettringite and was again examined by XRD. The specimen was then put back in the same solution, which had now been saturated with salt, and left for about a month before being examined by XRD. This XRD monitoring was continued for another month.

The results are summarized in Table 4. There was a sharp increase in the amount of ettringite when the month-old specimen was exposed to additional sulfate. There was formation of chloroaluminate without detriment to the ettringite when the solution was saturated with salt for a month; an additional month of exposure to the combined sulfate and chloride solution produced little change. This work is considered significant because it shows that if ettringite is allowed to form in a salt-free environment before exposure to the addition of salt, there will be only slight formation of chloroaluminate. The amount of ettringite will remain essentially stable. 


\section{Table 4}

Relative Amounts of Ettringite and Chloroaluminate in a Cement Paste ${ }^{1}$ as Determined by XRD

\begin{tabular}{|c|c|c|}
\hline \multirow[b]{2}{*}{ Sample } & \multicolumn{2}{|c|}{ Relative Amounts, XRD Chart Units } \\
\hline & $\begin{array}{l}\text { Ettringite } \\
(0.97 \mathrm{~nm})\end{array}$ & $\begin{array}{l}\text { Chloroaluminate } \\
(0.78 \mathrm{~nm})\end{array}$ \\
\hline About 1 month in sealed vials & $12^{2}$ & Not present ${ }^{3}$ \\
\hline $\begin{array}{l}\text { Additional month in solution saturated } \\
\text { with calcium sulfate }\end{array}$ & 45 & Not present ${ }^{3}$ \\
\hline $\begin{array}{l}\text { Additional month in solution saturated } \\
\text { with calcium sulfate and } \mathrm{NaCl}\end{array}$ & 45 & 5 \\
\hline Second month in same solution as above & 40 & 5 \\
\hline \multicolumn{3}{|c|}{$\begin{array}{l}{ }^{1} \mathrm{RC} 688(3) \text { and water }(0.5 \mathrm{w} / \mathrm{c}) \text { kept at about } 23^{\circ} \mathrm{C} \text {. } \\
2 \text { About half ettringite and half monosulfoaluminate. } \\
{ }^{3} \text { A small amount of } 0.78 \text { to } 0.79 \mathrm{~nm} \text { material was present. This was probably } \\
\text { tetracalcium-aluminate carbonate- } 11 \text {-hydrate (monocarboaluminate). }\end{array}$} \\
\hline
\end{tabular}




\section{Discussion}

The focus of this review has been on the effects of high chloride contents on performance of expansive mixtures. In general, the results indicate longterm coexistence of chloroaluminate and ettringite phases and no degradation of physical properties. Therefore, it is concluded that there is no evidence for inherent incompatibility in such mixtures. However, this review did not focus on the scenario in which sulfate ion is derived in large quantities from external sources. The literature indicates that under such conditions, ettringite is probably the preferred phase. The central question is whether or not replacement of chloroaluminate with ettringite after some extended curing time would result in degradation of properties, as is the case of classical sulfate attack.

Geochemical work should focus on durability of candidate materials in the kinds of environmental exposures expected to be encountered in their use. Of particular concern is the effect of sulfates in ground waters on ettringite-based expansive mixtures, since such mixtures must have relatively high levels of aluminates, either derived from the portland cement, the pozzolan, or other cementitious components. If the ratio of chemically active aluminates in cements and pozzolans or slags to the soluble sulfates in the mixture is such that all of the aluminates can be converted to ettringite, then there is little likelihood that harmful internal expansion will take place if additional sulfate in solution enters from the environment. This is the recipe for sulfateresistant expansive-cement concrete.

Historically, the property most frequently monitored and assumed to indicate longevity was strength. But as explained by Wakeley (1987), other factors are more important in a repository environment. With the recent emphasis on intrusion scenarios, low permeability and resistance to dissolution have become more critical. These properties are not necessarily related to strength, and should be studied specifically. 


\section{References}

Ben-Yair, M. (1974). "The effect of chlorides on concrete in hot and arid regions," Cement and Concrete Research 4, 405-416.

Boa, J. A. (1978). "Borehole plugging program (waste disposal) report 1, initial investigations and preliminary data," Miscellaneous Paper C-78-1, U.S. Army Engineer Waterways Experiment Station, Vicksburg, MS.

Buck, A. D., Boa, J. A., and Walley, D. M. (1985). "Development of a sanded expansive salt grout for repository sealing application," Miscellaneous Paper SL-85-11, U.S. Army Engineer Waterways Experiment Station, Vicksburg, MS.

Buck, A. D., Burkes, J. P., and Rhoderick, J. E. (1981). "Examination of ERDA-10 grout specimens at different ages," Miscellaneous Paper SL81-20, U.S. Army Engineer Waterways Experiment Station, Vicksburg, MS. Also issued as ONWI-341 (USAE-WES SL-81-20), Aug 81.

Buck, A. D. (1982). "Grout formulations for nuclear waste isolation," Miscellaneous Paper SL-82-6, U.S. Army Engineer Waterways Experiment Station, Vicksburg, MS.

- (1984). "Workability of fluid hydraulic cement systems containing salt," Miscellaneous Paper SL-84-10, U.S. Army Engineer Waterways Experiment Station, Vicksburg, MS.

. (1985a). "Development of two candidate concrete mixtures (salt, nonsalt) for repository sealing applications," Miscellaneous Paper SL85-8, U.S. Army Engineer Waterways Experiment Station Vicksburg, MS.

. (1985b). "Development of a sanded nonsalt expansive grout for repository sealing application," Miscellaneous Paper SL-85-6, U.S. Army Engineer Waterways Experiment Station, Vicksburg, MS. 
Grutzeck, M. W., and Roy, D. M. (1985). "Experimental characterization and stability of salt- and nonsalt-containing grouts and mortars (BCT-1Fand BCT-1FF-related)," BMI/ONWI-568, Office of Nuclear Waste Isolation, Battelle Memorial Institute, Columbus, $\mathrm{OH}$.

Gulick, C. W. (1978). "Borehole plugging materials development program," Sandia National Laboratories SAND-78-0789, Albuquerque, NM.

(1979). "Borehole plugging program, plugging or ERDA No. 10 drill hole," Sandia National Laboratories SAND-79-0789, Albuquerque, NM.

Gulick, C. W., Boa, J. A., Walley, D. M., and Buck, A. D. (1980). "Borehole plugging materials development program, report 2," Sandia National Laboratories SAND-79-1514, Albuquerque, NM.

Gulick, C. W., Boa, J. A., and Buck, A. D. (1980). "Bell canyon test (BCT) cement development report," Sandia National Laboratories SAND80-0358C, Albuquerque, NM.

. (1980). "Bell canyon test (BCT) cement grout development report," Sandia National Laboratories SAND-80-1928, Albuquerque, NM.

. (1982). "Borehole plugging materials development program, report 3," Sandia National Laboratories SAND-81-0065, Albuquerque, NM.

Jensen, H. U., and Pratt, P. L. (1989). "The binding of chloride ions by pozzolanic product in fly ash cement blends," Advances in Cement Research 2, 121-129.

Lerch, W., Ashton, F. W., and Bogue, R. H. (1929). "The sulfoaluminates of calcium," Bureau of Standards Journal of Research, 715-731.

Ogawa, K., and Roy, D. M. (1981). " $\mathrm{C}_{4} \mathrm{~A}_{3} \bar{S}$ hydration ettringite formation, and its expansion mechanism: I. Expansion; ettringite stability," Cement and Concrete Research 11, 741-750.

Poole, T. S., and Wakeley, L. D. (1992). "Length change and strength development of candidate cement-based sealing mixtures for the WIPP" (miscellaneous paper in preparation), U.S. Army Engineer Waterways Experiment Station, Vicksburg, MS.

Rhoderick, J. E., and Buck, A. D. (1981). "Borehole plugging program (waste disposal), report 2, petrographic examination of several four-year old laboratory developed grout mixtures," Miscellaneous Paper C-78-1, U.S. Army Engineer Waterways Experiment Station, Vicksburg, MS. Also issued by Office of Nuclear Waste Isolation (ONWI) as ONWI-342 (USAE-WES C-78-1) Sep 81. 
Roberts, M. H. (1962). "Effect of calcium chloride on the durability of pretensioned wire in prestressed concrete," Magazine of Concrete Research $42,143$.

Roy, D. M., Grutzeck, M. W., Mather, K., and Buck, A. D. (1982). "PSU/WES interlaboratory comparative methodology study of an experimental cementitious repository seal material, report 2, final results," Miscellaneous Paper SL-81-2, U.S. Army Engineer Waterways Experiment Station, Vicksburg, MS. Also published as ONWI-324, Sep 81.

Wakeley, L. D. (1987). "Durability of a chloride-saturated concrete for sealing radioactive wastes in bedded rock salt," Concrete Durability, Katharine and Bryant Mather International Conference, J. M. Scanlon, ed., American Concrete Institute, SP 100, Detroit, MI, 587-598.

Wakeley, L. D., and Walley, D. M. (1986). "Development and field placement of an expansive salt-saturated concrete (ESC) for the waste isolation pilot plant (WIPP)," Technical Report SL-86-36, U.S. Army Engineer Waterways Experiment Station, Vicksburg, MS. 
Public reporting burden for this collection of information is estimated to average 1 hour per response. including the time for reviewing instructions, searching existing data sources. collection of information, including suggestions for reducing this burden. Davis Highway. Suite 1204, Arlington, VA 22202-4302, and to the Office of Management and Budget, Paperwices. Director

\section{TITLE AND SUBTITLE}

April 1993

\section{REPORT TYPE AND DATES COVERED}

Final report

Stability of Calcium Chloroaluminate and Calcium Sulfoaluminate Phases in Hydraulic-Cement Mixtures

6. AUTHOR(S)

Toy S. Poole

\section{PERFORMING ORGANIZATION NAME(S) AND ADDRESS(ES)}

U.S. Army Engineer Waterways Experiment Station

Structures Laboratory

3909 Halls Ferry Road

Vicksburg, MS 39180-6199

\section{FUNDING NUMBERS}

9. SPONSORING/MONITORING AGENCY NAME(S) AND ADDRESS(ES)

10. SPONSORING/MONITORING

AGENCY REPORT NUMBER

U.S. Army Corps of Engineers

Washington, DC 20314-1000

\section{SUPPLEMENTARY NOTES}

Available from National Technical Information Service, 5285 Port Royal Road, Springfield, VA 22161.

12a. DISTRIBUTION/AVAILABILITY STATEMENT

Approved for public release; distribution is unlimited.

\section{ABSTRACT (Maximum 200 words)}

For many reasons and many years, candidate cement-based materials for closure of the Waste Isolation Pilot Plant (WIPP) have been proportioned with components to make them both salt-saturated and expansive. The chloride and sulfate phases that form when these materials hydrate have the potential to be chemically unstable if chemical conditions shift. Interconversions between these phases were considered a potential threat to grout or concrete stability and were the focus of extensive research during the 1980 's.

A review of published research from other sources and of both published and unpublished research from the WES revealed that these phase transformations do occur in conditions similar to those of the WIPP repository, but that these changes pose little threat to the integrity of cement-based plugging and sealing materials.

\section{SUBJECT TERMS}

Calcium chloroaluminate

Calcium sulfoaluminate

Chemical stability

17. SECURITY CLASSIFICATION OF REPORT
Ettringite

Friedel's salt
15. NUMBER OF PAGES

20

16. PRICE CODE

20. LIMITATION OF ABSTRACT

SECURITY CLASSIFICATION OF THIS PAGE

UNCLASSIFIED
19. SECURITY CLASSIFICATION OF ABSTRACT 